\title{
Exchange Rates and Financial Performance Effect on Conventional Bank Third Party Funds in Indonesia
}

\author{
Dini Hariyanti ${ }^{1}$, Soeharjoto ${ }^{2}$, Debbie Aryani Tribudhi ${ }^{3}$ \\ \{dinihariyanti@trisakti.ac.id ${ }^{1}$, soeharjoto@trisakti.ac.id ${ }^{2}$, debbie.aryani@trisakti.ac.id ${ }^{3}$ \} \\ Faculty of Economics and Business, Universitas Trisakti, Indonesia ${ }^{1,2,3}$
}

\begin{abstract}
Banks are intermediary institutions that help economic activities require cheap funds from Third Party Funds. Based on Business Activities IV book in Conventional Banks, commercial banks can still compete in the financial market, but with the volatility of Exchange Rates and Financial Performance will affect people's decisions in save their funds in the bank. Aims of this study is to find out the factors that affect Third Party Funds. Used monthly data from 2017-2020, with Error Correction Model as analysis regression method. Third Party Funds is dependent variables and Return on Assets (-1), Loan to Deposit Ratio, Interest, Net Interest Margin, and Exchange Rate are independent variable. Results shown, in short and long term, Exchange Rate has a positive and significant impact on Third Party Funds. In short terms, Net Interest Margin has a positive and significant effect on Third Party Funds, but not in the long term. Loan to Deposit Ratio negatively and significantly affects Third Party Funds in the short term but not in the long term. Return on Assets (-1) and Interest have no effect on Third Party Funds in the short and long term. Peoples who save their funds in the bank, think rationally, it is more concerned with the profit obtained with a small risk. Banks, governments, and international banking institutions need to maintain public trust by coordinating and cooperating intensively.
\end{abstract}

Keywords: Third Party Funds; Exchange Rate; Financial Performance

\section{Introduction}

Banking is the driving force in supporting the success of development in Indonesia [1]. As an intermediary institution, it helps smooth the transaction of economic activity, also to accelerate economic growth [2]. However, banking as a business entity has an interest in profit [3]. Therefore, in its activities trying to obtain a large profit but quickly, with a small risk by using funds derived from the bank and its customers [4].

In order to facilitate their activities, banks strive to collect Third Party Funds optimally [5]. The funds are important for banks because it obtains cheap funds from the public, which is used to increase profit, by lending Third Party Funds to businesses, thus gain the benefit from the spread between loan interest rates and savings [6]. Banks seeks various ways and systems in order to gain the trust of fund owners, in order to seize increasingly fierce interbank competition [7] Competition between banks are increasing, to have an impact, Indonesia uses dual banking system [8]. Sharia banking as a newcomer, has performed well, especially in the growth of Third Party Funds and financing [9]. This condition is strengthened by having a 
Capital Adequacy Ratio above the decree of the financial services authority [10]. However, its existence nominally is still under conventional banking. Because of the existence of conventional banking is longer so that its assets, products, and marketing strategies become more established.

International banking management are impact by global economic crisis, in order to avoid the failure of systemic-impacting banks, Basel Committee on Banking Supervision, making Basel III agreement [11]. Indonesian banks follow this agreement, especially Commercial Banks who at Business Groups III and IV category. The most established banks in conventional banking entered into Commercial Banks by Business Group IV category, and sharia banking entered to Commercial Banks based on Business Group III category. This makes conventional banking category of Commercial Banks based on Group IV still the main choice for fund owners. As for the impact, during 2017-2020, Third Party Funds growth average is 12.55 at commercial banks based on Group IV with an increasing trend. The growth is still in the low category considering its large market share, so it needs to be improved again in order to optimize profit, in order to increase investor confidence.

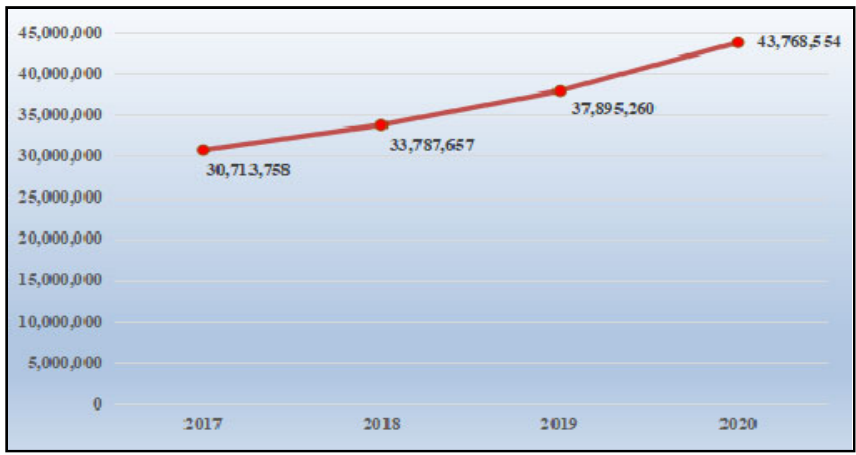

Fig. 1. Third Party Funds average of Commercial Banks by Group IV in 2017-2020 (Billion Rupiah).

Source: Research processed data, 2021.

Conventional banks are still able to compete in the financial markets. Due to the high public confidence in its performance. However, increase of opening economic system resulted in Exchange Rate changes on macro-economic turmoil that have a big impact on the national economy. In its activities, people behave rationally, so as to secure and develop their assets by considering the Banking Performance in the form of Interest, Return on Assets (-1), Net Interest Margin, and Loan to Deposit Ratio. Public confidence in conventional banking is still high, so bank can optimize its ability to raise public funds to support its activities. Nevertheless, public remains cautious in efforts to develop their funds in the banking industry that given them facing liquidity risks. Therefore, it is necessary to conduct research on the determination of conventional banks Third Party Funds in Indonesia.

\section{Theoritical Review}

Mainstream economic theory considers every human being to behave homoeconomicly, so that in his activities it is done rationally[12]. As for the assumption, man in acting seeks to obtain optimal benefits (utility maximization) and the individual is an agent that can take into 
account the consequences of any alternative of his actions [13] Therefore, rational decisionmaking is at the heart of the utility theory of homoeconomic behavior [14].

Ramsey with consumer optimization developed it into an exogenous savings rate model [15]. In this model, households strive to optimize the use of their income for consumption and saving between times. The obstacles faced by the limited funds owned. However, the increasing number of household members due to obtaining offspring, leads to increasing household needs to infinity. This will increase per capita consumption over time. Household seeks to allocate funds to be invested by reducing its consumption, when there is an opportunity to obtain a high return from capital. It can be realized by increasing public knowledge and information, so it will increase public awareness investing. Company will be easier to obtain additional capital from banks to develop its business, that can increase production and labor absorption, which has implications for increasing national income.

Facing financial problems, customer looking for as much information as possible and analyzed with their knowledge before they make a decision, so make it easier for customers to choose several saving options. After choose it, customer will make a saving decision. When a customer has become a certain bank customer, customer will respond if there is a change in the information and knowledge they have to become regular customer or switch to another bank. Community behaves rationally to gain profit but still pays attention to the risks it faces when carrying out this action. Therefore, Ramsey theory can be used as the basic for customer decision making at saving by paying attention to macroeconomic conditions in the form of Exchange Rate and Banking Performance in the form of the company's ability to profit in the previous year in the form of Return on Assets (-1), efficiency in the form of Net Interest Margin, risks faced in the form of Loan to Deposit Ratio, and Interest profit that will be received.

Research on factors that affect Third Party Funds has been conducted several studies with mixed results. [16]revealed that Exchange Rate affects Third Party Funds, but [17], obtained Exchange Rate results have no effect on Third Party Funds. [18], was obtained that Interest has a positive and significant effect on Third Party Funds, while [19], find that Interest had no effect on Third Party Funds. [20], obtained that Return on Assets positively affects Third Party Funds. [21], with the findings of Financing to Deposit Ratio affects Third Party Funds, but [22], obtained that Financing to Deposit Ratio has no effect on Third Party Funds. [23], with efficiency findings have a positive and significant influence on Third Party Funds.

\subsection{Hypothesis Development}

\section{a) The relationship between Exchange Rates and Third Party Funds}

Macroeconomic conditions play a major role in national economy. This can happen due to changes in the Exchange Rate that can result in a decrease in purchasing power, so people strive to secure the real value of their money by making various investment alternatives but still calculate the risks that facing them. Bank has been anticipated this condition by offering more benefits to keep liquid funds. Fund owner earn twice as much as the difference in Exchange Rates and offers higher Interest Rates from banks with minimal risk. This situation is in accordance with 16. Therefore, the hypothesis is Exchange Rate has a positive and significant effect on Third Party Funds.

\section{b) Relationship between Interest Rates and Third Party Funds}


People keep their funds in banks with the aim of obtaining gain from Interest income. However, in making their investments, fund owners have a variety of investment alternatives, so they do an analysis of their information and knowledge. This situation makes bank seek to attract fund owners Interests by providing them high rates so that liquidity increases that can improve the performance of the bank. Its accordance with the research results of 18 . Therefore, the hypothesis is Interest Rates have a positive effect on Third Party Funds.

\section{c) Return on Assets (-1) relationship with Third Party Funds}

A well performing bank can increase its assets through Return on Assets. Publics still considering the principle of prudence when they keeps their funds by paying attention to the banks historical performance in the past period. Increasing of Return on Assets (-1) indicates the bank's ability to grow its business to be more flexible and its assets will increase. This has an impact on the investors and customers increasing confidence at banking. This condition is in accordance with the 20. Therefore, it can be hypotheses that Return on Assets (-1) positively affects Third Party Funds.

\section{d) Net Interest Margin Influence to Third Party Funds}

Net Interest Margin can describe bank's operations efficiency. This is inseparable from Net Interest Margin which is a spread between savings rates and loan interest rates. Efficient banking can increase its spreads so the increasing profits that can be used to improve customer services. The situation is in accordance with 23. Therefore, the hypotheses is Net Interest Margin has a positive effect on Third Party Funds.

\section{e) Relationship between Loan to Deposit Ratio with Third Party Funds}

Banking is a trust institution, so it is necessary to maintain its liquidity through the performance of the Loan to Deposit Ratio. Aim of the investors are to make profit with the information and knowledge they have and pay attention to the risks that will occur especially related to banking liquidity reflected in the Loan to Deposit Ratio. This is accordance with 21 . The hypotheses that Loan to Deposit Ratio negatively affects Third Party Funds.

\section{Research Method}

This study was conducted to determine the factors that affect Third Party Funds in conventional banks in Indonesia. Time series monthly data from 2017-2020 from the financial services authority and Bank Indonesia. Research method uses Error Correction Model (ECM) regression analysis. Third Party Funds are dependent variables and Exchange Rate, Interest, Return on Asset (-1), Net Interest Margin, and Loan to Deposit Ratio are independent variables. As for the similarities:

$$
\begin{aligned}
& \mathrm{TPF}_{\mathrm{t}}=\beta_{1}+\beta_{2} \mathrm{ER}+\beta_{2} \text { Interest }_{\mathrm{t}}+\beta_{3} \mathrm{ROA}(-1)_{\mathrm{t}}+\beta_{4} \mathrm{NIM}_{\mathrm{t}}+\beta_{5} \mathrm{LDR}_{\mathrm{t}}+\varepsilon_{\mathrm{t}} \\
& \text { Information: } \\
& \text { TPF } \quad=\text { Third Party Funds. } \\
& \text { ER } \quad \text { Exchange Rate. }
\end{aligned}
$$




$$
\begin{aligned}
& \text { Interest } \quad=\text { Interest Rate. } \\
& \text { ROA }(-1)=\text { Return to Asset }(-1) \\
& \text { NIM } \quad=\text { Net Interest Margin. } \\
& \text { LDR } \quad=\text { Loan to Deposit Ratio. }
\end{aligned}
$$

Root unit test is to find out that used data is already stationer and then co-integration test can be implemented, and if both test pass, it can be used to estimate factors that affect Third Party Funds using time series data with error correction model analysis regression method. Data should be stationer and co integrated. If the value is probability $\mathrm{ADF}<0.05$ at level or probability $\mathrm{ADF}<0.05$ on 1 st difference, it is stationary data. Furthermore, a co-integration test is conducted, provided that if probability ECT (Residual) $<0.05$ at the integrated data level. After the stationary test and co-integration, continued by making a regression test error correction model analysis to obtain long-term and short-term equations. Normality and classical assumptions in the form of autocorrelation, multicollinearity, and heteroscedasticities used in order to have a model that can be predict powerfully.

\section{Results, Analysis, and Discussion}

Third Party Funds, Return on Assets (-1), Loan to Deposit Ratio, Interest, Net Interest Margin, and Exchange Rate have diverse data with fluctuating trends. Average value of Third Party Funds is 3045109 billion rupiah with a standard deviation of 436382 billion rupiah, whose maximum value in 2020.12 amounted to 3897941 billion rupiah and the minimum in 2017.1 amounted to 2288114 billion rupiah. Average value Return on Assets (-1) is 2.93 percent with a standard deviation of 0.33 percent, whose maximum value in 2019.2 is 3.29 percent and the minimum in 2020.12 is 1.96 percent. Average value of Loan to Deposit Ratio is 87.87 percent with a standard deviation of 3.28 percent, whose maximum value in 2019.1 is 92.69 percent and the minimum in 2020.12 is 80.11 percent. Average Value of Interest is 1.45 percent with a standard deviation of 0.50 percent, whose maximum value in 2018.1 is 3.32 percent and the minimum in 2020.11 and 2020.12 is 0.66 percent. Average value of Net Interest Margin is 5.58 percent with a standard deviation of 0.41 percent, whose maximum value in 2017.1 and 2017.3 was 6.08 percent and the minimum in 2020.4 was 4.63 percent. Average value of Exchange Rate is 14095 rupiah per 1 US dollar with a standard deviation of 592 rupiah per 1 US dollar, whose maximum value in 2020.4 is 13297 rupiah per 1 US dollar and minimum in 2017.6 of 15867 rupiah per 1 US dollar.

Table 1. TPF, ROA (-1), LDR, Interest, NIM, and ER Descriptive

\begin{tabular}{ccccccc}
\hline & TPF & ROA (-1) & LDR & Interest & NIM & ER \\
\hline AVG & 3045109 & 2.93 & 87.87 & 1.45 & 5.58 & 14095 \\
MAX & 3897941 & 3.29 & 92.69 & 2.32 & 6.08 & 13297 \\
MIN & 2288114 & 1.96 & 80.11 & 0.66 & 4.63 & 15867 \\
STD. DEV. & 436382 & 0.33 & 3.28 & 0.50 & 0.41 & 592 \\
\hline \multicolumn{7}{c}{ Source: Processed data research 2021 }
\end{tabular}

Probability value of Exchange Rate is $0.3400>0.05$ and value $0.0000<0.05$ on first difference. Probability of interest is $0.8624>0.05$ and on first difference probability is $0.0000<0.05$. Probability of Loan to Deposit Ratio is $0.7145>0.05$ and on first difference probability is $0.0002<0.05$. Probability of Net Interest Margin is $0.9195>0.05$ and probability value on first difference is $0.0000<0.05$. Return on Assets $(-1)$ has a probability level at 
$0.9756>0.05$ and at first difference has probability point $0.0000<0.05$. Third Party Funds has a probability level $0.9999>0.05$ and probability $0.0130<0.05$ at the 1 st difference. In the cointegration test obtained results with probability value. $0.0004<0.0004$, so the data is integrated. This research has passed the stationary test and co-integration, so it can be used to estimate with the error correction model (ECM) analysis regression method.

\subsection{Long-term model}

Result of this study obtained the value of Adj. R-Squared is 0.890812 for long term, which means that 89.0812 percent of Third Party Funds can be explained Return on Assets (-1), Loan to Deposit Ratio, Interest, Net Interest Margin, Exchange Rate and the remaining 10.9188 percent is influenced by other variables that are not included in the model. Based on long-term estimation results, probability value. F-statistics are generated at $0.00000<0.05$, which means that at least one of the Return on Assets (-1), Loan to Deposit Ratio, Interest, Net Interest Margin, Exchange Rate in the long term can affect Third Party Funds.

Table 2. Long Term Regression Result

\begin{tabular}{ccllc}
\hline \multicolumn{1}{c}{ Variable } & Coefficient & Std. Error & t-Statistic & Prob. \\
\hline C & 4723029. & 1786539. & 2.643676 & 0.0116 \\
ROA (-1) & -164830.9 & 146448.9 & -1.125518 & 0.2669 \\
LDR & 5333.206 & 12144.46 & 0.439147 & 0.6629 \\
Interest & -259274.9 & 74455.40 & -3.482285 & 0.0012 \\
NIM & -539315.7 & 157207.6 & -3.430595 & 0.0014 \\
ER & 122.3835 & 63.27979 & 1.934006 & 0.0600 \\
\hline R-squared & 0.902680 & Mean dependent var & 3061215 \\
Adjusted R-squared & 0.890812 & S.D. dependent var & 426434.7 \\
S.E. of regression & 140909.4 & Akaike info criterion & 26.66837 \\
Sum squared resid & $8.14 \mathrm{E}+11$ & Schwarz criterion & 26.90455 \\
Log likelihood & -620.7066 & Hannan-Quinn criter. & 26.75725 \\
F-statistic & 76.05834 & Durbin-Watson stat & 1.243789 \\
Prob(F-statistic) & 0.000000 & & & \\
\hline
\end{tabular}

Source: Processed data by Research 2021

t-test results can be used to determine individually in the long term from Return on Assets (1), Loan to Deposit Ratio, Interest, Net Interest Margin, Exchange Rate that can be influential and significant to Third Party Funds. Return on Assets (-1) returns the t-value probability $0.2669 / 2=0.13345>0.05$ with a coefficient value of -164830.9 , means Return on Assets $(-1)$ has no effect on Third Party Funds in the long term. Results are contrary to [20]. Loan to Deposit Ratio generates t value probability $0.6629 / 2=0.331345>0.05$ with a coefficient value of 5333.206, means that the Loan to Deposit Ratio does not affect Third Party Funds in the long term. Similar to [22]. Interest generates a t-value probability $0.0012 / 2=0.0006<0.05$ with a coefficient value of -259274.9 , means Interest has no effect on Third Party Funds in the long term. The situation is accordance with [19]. Net Interest Margin generates a Prob value. $t$ of $0.0014 / 2=0.0007<0.05$ with a coefficient value of -539315.7 , means at long run, Net Interest Margin has no effect on Third Party Funds. This is not in accordance with [23]. Exchange Rate generates a Probability value $t$ of $0.0600 / 2=0.0300<0.05$ with a coefficient value of 122.3835 , means at the long run, Exchange Rate has a positive and significant effect on Third Party Funds. This condition, in accordance with [16]. 


\subsection{Short-Term Model}

Results of this study obtained amount of Adj value. R-Squared from short-term is 0.425115, which means that 42.5115 percent of Third Party Funds can be explained Return on Assets (-1), Loan to Deposit Ratio, Interest, Net Interest Margin, Exchange Rate and the remaining 57.4885 percent are affected by other variables not included in the model. Based on long-term estimates, F-statistics probability value $0.000077<0.05$, means that at least one of the Return on Assets (-1), Loan to Deposit Ratio, Interest, Net Interest Margin, Exchange Rate in short term may affect Third Party Funds. The ECT coefficient (-1) is obtained at -0.12941 with prob. $t$ amounted to 0.0397 , which means at short term, ECT (-1) variable negatively and significantly affects Third Party Funds, so at short term can be used the ECM model.

Table 3. Short Term Regression

\begin{tabular}{|c|c|c|c|c|}
\hline Variable & Coefficient & Std. Error & t-Statistic & Prob. \\
\hline $\mathrm{C}$ & 27899.37 & 6893.131 & 4.047416 & 0.0002 \\
\hline $\mathrm{D}(\mathrm{ROA}(-1))$ & -71389.74 & 50072.63 & -1.425724 & 0.1619 \\
\hline $\mathrm{D}(\mathrm{LDR})$ & -27024.59 & 7693.174 & -3.512801 & 0.0011 \\
\hline $\mathrm{D}$ (Interest) & 15325.64 & 44028.64 & 0.348083 & 0.7296 \\
\hline $\mathrm{D}(\mathrm{NIM})$ & 153454.4 & 49430.81 & 3.104427 & 0.0035 \\
\hline $\mathrm{D}(\mathrm{ER})$ & 59.24907 & 22.99070 & 2.577089 & 0.0139 \\
\hline $\operatorname{ECT}(-1)$ & -0.129411 & 0.060808 & -2.128199 & 0.0397 \\
\hline R-squared & 0.501767 & \multicolumn{2}{|c|}{ Mean dependent var } & 31162.74 \\
\hline Adjusted R-squared & 0.425115 & \multicolumn{2}{|c|}{ S.D. dependent var } & 58172.75 \\
\hline S.E. of regression & 44107.25 & \multicolumn{2}{|c|}{ Akaike info criterion } & 24.36590 \\
\hline Sum squared resid & $7.59 \mathrm{E}+10$ & \multicolumn{2}{|c|}{ Schwarz criterion } & 24.64418 \\
\hline Log likelihood & -553.4158 & \multirow{2}{*}{\multicolumn{2}{|c|}{$\begin{array}{l}\text { Hannan-Quinn criter. } \\
\text { Durbin-Watson stat }\end{array}$}} & 24.47015 \\
\hline F-statistic & 6.546093 & & & 2.258908 \\
\hline Prob(F-statistic) & 0.000077 & & & \\
\hline
\end{tabular}

Sources: Processed Data by Research, 2021

At short term, t-test results can be used to determine individually of Return on Assets (-1), Loan to Deposit Ratio, Interest, Net Interest Margin, Exchange Rate which can be influential and significant to Third Party Funds. Return on Assets (-1) generates a probability value $t$ amounted to $0.1619 / 2=0.08095>0.05$ with a coefficient value of -27024.59 , means that at short term, Return on Assets (-1) has no effect on Third Party Funds. This is contrary to [20]. Loan to Deposit Ratio generates a t Probability value amounted to $0.0011 / 2=0.00055<0.05$ with a coefficient value of -27024.59 , means at short term, Loan to Deposit Ratio negatively and significantly affects Third Party Funds, accordance with [21]. Interest generates a probability value of $0.7296 / 2=0.3648>0.05$ with a coefficient value of 15325.64 , means that in short term, Interest does not affect Third Party Funds. This accordance with of [19]. Net Interest Margin returns the $\mathrm{t}$ value Prob. $0.0035 / 2=0.00175<0.05$ with a coefficient of 153454, means that at short term, Net Interest Margin has a positive and significant effect on Third Party Funds. It is same to [23]. Exchange Rate returns the $t$ value probability of $0.0397 / 2=0.01985<0.05$ with a coefficient value of 59.24907 , means that in the short term, the Variable Exchange Rate has a positive and significant impact on Third Party Funds. Results of this study is accordance with [16].

This model can be used optimally when normality and assumption tests have been conducted. Normality test result obtained normally distributed data. All VIF values are below 10, namely Return on Assets (-1) of 6.506135, Net Interest Margin of 9.386692, Loan to 
Deposit Ratio of 3.743448, Exchange Rate of 3.207432, and Interest of 3.230266, so that the model is free from multicollinearity. The run test result obtained R-Square value in the model of $0.541479>0.05$, so that the model is free from autocorrelation problems. Glesjer test obtained prob F-stat value of 0.0690 and $0 b s^{*} \mathrm{R}$-squared of 0.0734 greater than 0.05 , so the model is free from heteroscedasticity problems. The results of the classic assumption testing proved the model can be used powerfully.

At digital age, world's economy is become limitless. World macro-economic turmoil will result in changes at Exchange Rate that eventually impact the national economy, so government and banks needs to anticipated this situation quickly in order to make conditions more conducive. People who think rationally with their information and knowledge will become increasingly critical in making policies to save their funds. The results of this study were obtained factors that affect Third Party Funds, namely Exchange Rate that has a positive influence in the short and long term, Net Interest Margin positively influenced in the short term, and Loan to Deposit Ratio negatively and significantly in the short term. Return on Assets (-1) is the other factors that do not affect Third Party Funds and interest does not have affect to Third Party Funds in the short and long term, while Net Interest Margin and Loan to Deposit Ratio have no effect in the long term. Accordance with Ramsey theory that humans think rationally with the information and knowledge they have is used to analyze and make decisions to invest by reducing their consumption [15]. However, they considering the risks while make a decision. Peoples who keep their funds in the bank have tendencies to prioritize the security of their funds rather than gaining large profits with great risk. Governments, banks, and international banking institutions need to maintain public trust by coordinating and cooperating intensively, so with conducive conditions Third Party Funds which stored at banks will increase and national economic growth can rapidly increase.

\section{Conclusions, Limitations, and Recommendations}

Macroeconomics and financial performance play a role in improving Third Party Funds. All of them, inseparable from human nature as social beings who think rationally, so every action taken utilizes information and knowledge that has to be analyzed in order to obtain optimal profit, but still pay attention to the risks. This, makes capital owner trust to deposit their funds at bank. When stored their assets at banks, fund owner pay attention to several factors, especially macro-economic (Exchange Rate) and financial ratio (Return on Asset (-1)), Loan to Deposit Ratio, Net Interest Margin, and Interest. This research was conducted to determine the factors that affect Third Party Funds in conventional banks in Indonesia, with the method of regression analysis of error correction model in 2017-2020. Long term result of Exchange Rate has a positive and significant impact on Third Party Funds, but Return on Assets (-1), Loan to Deposits Ratio, Interest, Net Interest Margin has no effect on Third Party Funds. Exchange Rate and Net Interest Margin have a positive and significant effect on Third Party Funds at short term, while Loan to Deposit Ratio negatively and significantly affects Third Party Funds, but Return on Assets (-1) and Interest have no effect on Third Party Funds. Limitations of this research are due to the transition period of the Covid-19 pandemic, so the result is a tendency from fund owners to prioritize the security of their funds rather than the profits gained so that there are many financial ratios related to the profits that will be gained by the owner of the fund is not significant. In further research, we recommend using dummy variables before and after the Covid-19 pandemic and include other macroeconomic variables. 


\section{References}

[1] Soeharjoto, Tribudhi, D. A., Hariyanti, D. \& Tajib, E. Internal and External Factor that Influence Liquidity: Case of Conventional Banks in Indonesia. Int. J. Sci. Technol. Res. 9, 7066-7070 (2020).

[2] Petkovski, M. \& Kjosevski, J. Does Banking Sector Development Promote Economic Growth? An Empirical Analysis for Selected Countries in Central and South Eastern Europe. Econ. Res. Istraz. 27, 55-66 (2014).

[3] Peshkova, E. ., Kyurdzhiev, S. P. \& Martazanov, A. A. Strategy for Forming Financial Resources in the Context of a Conflict of Interests Between an Economic Entity and Its Creditors. Proceding of the International Science and Technology Conference "FarEastCon 2020" Smart Innovation, Systems and Technology, 227. Spinger. Singapore (2020).

[4] Werner, R. A. Can Banks Individually Create Money Out of Nothing? - the Theories and the Empirical Evidence. Int. Rev. Financ. Anal. 36, 1-19 (2014).

[5] Hasna, D. P., Ariyani, D. S., Ula, L. F., Putri, R. S. \& Prayitno, Y. H. The Effect Of Third-Party Funds And Liquidity (LDR) On Banking Profitability (ROA) (Case Study of BUMN Banks Listed on the Indonesia Stock Exchange From 2012 To 2019). Palarch's J. Archaeol. Egypt/Egyptology 17, 2914-2927 (2020).

[6] Septya, P. R., Taufik, P. A. \& Yusuf, Z. The Effect of Service Quality and Marketing Programs on Third Party Funds. Ilomata Int. J. Manag. 1, 8-12 (2019).

[7] Khan, M. M. \& Fasih, M. Impact of Service Quality on Customer Satisfaction and Customer Loyalty: Evidence from Banking Sector. Pakistan J. Commer. Soc. Sci. 8, 331-354 (2014).

[8] Nugroho, L., Utami, W., Sukmadilaga, C. \& Fitrijanti, T. The Urgency of Allignment Islamic Bank to Increasing the Outreach (Indonesia Evidence ). Int. J. Econ. Financ. Issues 7, 283-291 (2017).

[9] Nugroho, L., Mastur, A. A., Ulfa, Wahyono, T. \& Soeharjoto. Comparative Analysis of the Determinant Factors of Return on Assets between Islamic Commercial Banks (BUS) and Islamic Business Units (UUS). J. Econ. 17, 124-140 (2021).

[10] Chairunesia, W. Analysis of the Bank's Health Level and Its Effects on the Profitability of Sharia General Banks Listed in Indonesia's Financial Services Authority Period 2015-2018. Asian J. Econ. Bus. Account. 17, 38-53 (2020).

[11] Bunea, M. \& Dinu, V. The Basel III Impact on the Romanian Banks's Solvency. Montenegrin J. Econ. 15, 189-199 (2019).

[12] Simon, H. A Behavioral Model of Rational Choice. Q. J. Econ. 69, 99-118 (1955).

[13] Simon, H. A. Models of Bounded Rationality. (MIT Press, 1982).

[14] Bernoulli, D. Exposition of a New Theory on the Measurement of Risk. Econometrica 22, 23-36 (1954).

[15] Attanasio, O. P. Frank Ramsey's a Mathematical Theory of Saving. Econ. J. 125, 269294 (2015).

[16] Maulayati, R. R., Bahril, M. 'Adilah, Najiatun \& Herianingrum, S. Effect of Macroeconomic Variables on Third- Party Funds in Islamic Commercial Banks in Indonesia. J. Islam. Econ. Lariba 6, 19-40 (2020).

[17] Anik \& Prastiwi, I. E. Macro Economic Challenges and Third Party Funds of Islamic Commercial Banks in Indonesia. Shirkah J. Econ. Bus. 3, 127-152 (2018).

[18] Amaliawiati, L., Hendayana, Y. \& Sarumpaet, T. L. The Impact of Macroeconomics towards Islamic Banking Third Party Funds in Indonesia. Int. J. Innov. Creat. Chang. 
6, 291-303 (2019).

[19] Indiastary, D., Suprayogi, N. \& Indrawan, I. W. a Meta-Analysis of the Determinant of Third Party Fund on Islamic Banking in Indonesia. J. Ekon. dan Bisnis Islam (Journal Islam. Econ. Business) 6, 175-188 (2020).

[20] Firdausi, I. Analisis Pengaruh Kinerja Perbankan terhadap Dana Pihak Ketiga Bank Persero. J. Keuang. dan Perbank. 20, 487-495 (2016).

[21] Harahap, D. Determinan Dana Pihak Ketiga Bank Syariah di Indonesia: Model Vector Autoregresive. IQTISHADIA 10, 178-194 (2017).

[22] Hidayat, A. \& Sunarsi, D. Faktor-Faktor yang Mempengaruhi Dana Pihak Ketiga dan Dampaknya terhadap Profitabilitas. 1-12 (2017).

[23] Al Arif, M. N. R. A. \& Hanifah, H. Determinan Deposito Pada Bank Umum Syariah: Model Regresi Panel. J. Ekon. Kuantitatif Terap. 10, 39-46 (2017). 